\title{
Pengaruh Orientasi Kepemimpinan Dan Tingkat Penghargaan Terhadap Loyalitas Karyawan Di Universitas Lancang Kuning Pekanbaru
}

\author{
Abrar Tanjung ${ }^{1,2}$, M. Giatman 1 , Ambyar ${ }^{1}$ \\ DOI: https://doi.org/10.36339/jaspt.v4i1.282
}

1. Universitas Negeri Padang

2. Universitas Lancang Kuning Pekanbaru

\begin{abstract}
Human resources are people who design and produce goods or services, oversee quality, market products, allocate financial resources and formulate all strategies and objectives of the organization. Full and continuous management and utilization of existing human resources so that they can work optimally, effectively and productively in achieving organizational or company goals. Lancang Kuning University is an educational institution that has administrative and teaching and learning activities. The total number of employees or employees is 513, consisting of 377 educators and 144 education staff. Simultaneous Influence. Based on the results of the discussion, the simultaneous influence of leadership orientation and rewards on employee loyalty is $32.1 \%$, while the remaining $67.9 \%$, while the partial effect of multiple regression analysis shows that supervision has an influence on employee work discipline by 0.435 , awards have an influence to employee loyalty of 0.279 .
\end{abstract}

EMail

abrartanjung77@gmail.com

Submitted Januari 2020

Accepted : Juli 2020

Keywords: rewards, employees, leadership, data

\begin{abstract}
Abstrak
Pengelolaan dan pendayagunaan secara penuh dan berkesinambungan terhadap sumber daya manusia yang ada sehingga mereka dapat bekerja secara optimal, efektif dan produktif dalam mencapai tujuan organisasi atau perusahaan. Universitas Lancang Kuning merupakan suatu lembaga pendidikan yang mempunyai kegiatan admistrasi dan belajar mengajar. Adapun jumlah total pegawai atau karyawan sebanyak 513 orang yang terdiri dari tenaga pendidik sebanyak 377 orang dan tenaga kependidikan sebanyak 144 orang. Pengaruh Secara Simultan. Berdasarkan hasil pembahasan din peroleh Pengaruh Orientasi Kepemimpinan dan Penghargaan secara simultan terhadap loyalitas karyawan sebesar $32,1 \%$, sedangkan sisanya $67,9 \%$, sedangkan Pengaruh Secara Parsial Analisis regresi berganda menunjukkan bahwa pengawasan mempunyai pengaruh terhadap disiplin kerja karyawan sebesar 0,435 , penghargaan mempunyai pengaruh terhadap loyalitas karyawan sebesar 0,279.
\end{abstract}

Kata Kunci: penghargaan, karyawan, kepemimpinan, data
JAS-PT

JURNAL ANALISIS SISTEM PENDIDIKAN TINGG ISSN $2580-5339$ eISSN $2620-5718$

Volume 4

Nomor 1

JULI 2020

Hal $33-46$

FORUM DOSEN INDONESIA 


\section{PENDAHULUAN}

Pemimpin dan karyawan merupakan elemen penting dalam perusahaan yang memiliki peran penting dalam menjalankan sebuah perusahaan. Dewasa ini perkembangan bisnis yang semakin pesat dan tingkat persaingan yang semakin tajam membuat perusahaan harus meningkatkan dan mengembangkan performancenya disemua bidang. Setiap perusahaan memiliki cara agar perusahaannya dapat bertahan ditengah - tengah persaingan yang ketat, salah satunya bidang yang harus di tingkatkan ialah sumber daya manusia. Robbins dan Coulter yang (dalam T.Hermaya, 2014 : 16) "Proses pengkoordinasian kegiatan-kegiatan pekerjaan sehingga pekerjaan tersebut terselesaikan secara efisien dan efektif dan melalui orang lain" Didalam organisasi dan perusahaan dibutuhkan menajemen yang dapat mengatur serangkaian komponen termasuk orang-orang yang berada didalam organisasi tersebut. yang terdiri dari tindakan-tindakan perencanaan, pengorganisasian, penggerakan dan pengendalian. Stephen $P$. Robbins, Mary Coulter menyatakan bahwa manajemen melibatkan koordinasi dan mengawasi aktivitas kerja lainnya sehingga kegiatan mereka selesai dengan efektif dan efisien. Arti dari efisien itu sendiri adalah mendapatkan hasil output terbanyak dari input yang seminimal mungkin, sedangkan efektif adalah "melakukan hal yang benar", yaitu melakukan sebuah pekerjaan yang dapat membantu organisasi mencapai tujuannya (2016). Marwansyah juga menyatakan bahwa Manajemen Sumber Daya Manusia dapat diartikan sebagai pendayagunaan sumber daya manusia didalam organisasi, yang dilakukan melalui fungsi-fungsi perencanaan sumber daya manusia, perencanaan dan pengembangan karir, pemberian kompensasi dan kesejahteraan, dan hubungan industrial (Marwansyah, $2016: 16$ ).

Sumber daya manusia adalah penarikan, seleksi, pengembangan, pemeliharaan, dan penggunaan sumber daya manusia untuk mencapai baik tujuan-tujuan individu maupun organisasi (T. Handoko, 2014 : 20). Sedangkan menurut (Samsudin, 2014 : 20) Sumber daya manusia adalah orang-orang yang merancang dan menghasilkan barang atau jasa, mengawasi mutu,memasarkan produk, mengalokasikan sumber financial serta merumuskan seluruh strategi dan tujuan organisasi. Menurut (Samsudin, 2014 : 23) terdapat hal yang esensial dari manajemen sumber daya manusia adalah pengelolaan dan pendayagunaan secara penuh dan berkesinambungan terhadap sumber daya manusia yang ada sehingga mereka dapat bekerja secara optimal, efektif dan produktif dalam mencapai tujuan organisasi atau perusahaan.

Universitas Lancang Kuning merupakan salah satu Universitas swasta yang ada di LLDIKTI wilayah X. Didirikan oleh Yayasan Raja Ali Haji yang pada waktu itu di prakarsai oleh Gubernur Riau H. Imam Munandar. Sejak berdiri tahun 1982 hingga saat ini telah memiliki 9 Fakultas dengan 18 Program studi S1 dan 2 Program Studi Program Pascasarjana (S2). Universitas Lancang Kuning merupakan suatu lembaga pendidikan yang mempunyai kegiatan admistrasi dan belajar mengajar. Adapun jumlah total pegawai atau karyawan sebanyak 513 orang yang terdiri dari tenaga pendidik sebanyak 377 orang dan tenaga kependidikan sebanyak 144 orang.

Kepemimpinan merupakan faktor terpenting dalam suatu organisasi. Untuk memahami

JAS-PT

JURNAL ANALISIS SISTEM PENDIDIKAN TINGGI ISSN $2580-5339$ eISSN $2620-5718$ Volume 4

Nomor 1 JULI 2020 Hal 33 - 46

FORUM DOSEN INDONESIA gaya kepemimpinan terlebih dahulu kita ketahui definisi kepemimpinan menurut para ahli adalah sebagai berikut, Menurut Stogdi (dalam Dr. M. Sobry Sutikno, 2014 : 15), "Terdapat hampir sama banyaknya definisi tentang kepemimpinan dengan jumlah orang yang telah mencoba mendefinisikannya." Stogdill menyatakan bahwa, "Kepemimpinan sebagai konsep manajemen dapat dirumuskan dalam berbagai macam definisi tergantung dari mana titik tolak pemikirannya." Kepemimpinan dalam organisasi diarahkan untuk mempengaruhi orang-orang yang dipimpinnya, agar mau berbuat 
seperti yang diharapkan ataupun diarahkan oleh orang lain yang memimpinnya (Sutikno, 2014 : 22). Kepemimpinan menurut (Kartono, 2014 : 32) merupakan kekuatan aspirasional, kekuatan semangat, dan kekuatan moral yang kreatif, yang mampu mempengaruhi para anggota untuk mengubah sikap, sehingga mereka menjadi conform dengan keinginan pemimpin. Sedangkan menurut (Rivai, 2015 : 19) Kepemimpinan merupakan proses mempengaruhi dalam menentukan organisasi, memotivasi perilaku pengikut untuk mencapai tujuan, mempengaruhi untuk memperbaiki kelompok dan budayanya. Maka dapat disimpulkan bahwa kepemimpinan adalah suatu perilaku dengan tujuan tertentu untuk mempengaruhi aktivitas para anggota kelompok sehingga dapat mencapai tujuan bersama yang dirancang untuk memberikan manfaat individu dan organisasi

Orientasi kepemimpinan dapat diartikan juga dengan gaya kepemimpinan, gaya kepemimpinan Menurut (Thoha, 2013 : 49) bahwa Gaya Kepemimpinan merupakan norma perilaku yang digunakan oleh seseorang pada saat orang tersebut mencoba mempengaruhi perilaku orang lain seperti yang ia lihat. Selanjutnya menurut (Rivai, 2014 : 42) menyatakan Gaya Kepemimpinan adalah sekumpulan ciri yang digunakan pimpinan untuk memengaruhi bawahan agar sasaran organisasi tercapai atau dapat pula dikatakan bahwa gaya kepemimpinan adalah pola perilaku dan strategi yang disukai dan sering diterapkan oleh seorang pemimpin.

Pengertian kompensasi adalah sebagai berikut semua pendapatan yang berbentuk uang, barang langsung atau tidak langsung yang diterima karyawan sebagai imbalan atas jasa yang diberikan kepada perusahaan (Malayu S.P. Hasibuan, 2014 : 118). Menurut (Dessler, 2015 : 302) Kompensasi adalah segala bentuk pembayaran atau apresiasi yang diberikan kepada karyawan yang timbul akibat pekerjaan mereka. Sementara itu menurut Marihot Tua E.H. (dalam Sunyoto, 2015) mendefinisikan kompensasi adalah keseluruhan balas jasa yang diterima oleh karyawan sebagai akibat dari pelaksanaan pekerjaaan di organisasi dalam bentuk uang atau lainnya, yang dapat berupa gaji, upah, bonus, insentif dan tunjangan kesehatan, tunjangan hari raya, uang makan, uang cuti dan lain-lain.

\section{METODE PENELITIAN}

\section{Populasi dan Sampel}

Populasi merupakan seluruh komponen elemen yang menjadi perhatian dalam suatu penelitian atau seluruh kumpulan elemen yang digunakan dalam membuat beberapa kesimpulan. Elemen diartikan sebagai subjek dilakukannya pengukuran atau dikenal dengan istilah unit penelitian. Populasi dalam penelitian ini adalah para Karyawan di lingkungan Universitas Lancang Kuning yaitu sebanyak 80 orang. Pemilihan karyawan saja sebagai populasi penelitian karena dapat mempermudah penelitian dan tidak terlalu banyak memakan waktu. Selain itu, populasi ini juga dapat mewakili dari semua satuan kerja sistem yang pada perusahaan. Dalam penelitian ini, sampel diambil para Karyawan di lingkungan Universitas Lancang Kuning. Berdasarkan survei yang dilakukan, maka dalam pengambilan sampel, peneliti memutuskan untuk menggunakan teknik random sampling yaitu mencakup orang-orang yang terdapat pada populasi tersebut, sehingga setiap anggota populasi memiliki hak yang sama untuk dijadikan responden dalam penelitian ini. Sampel dalam penelitian ini adalah para Karyawan di lingkungan Universitas Lancang Kuning Pekanbaru yaitu sebanyak 80 orang.

\section{Definisi Operasional Variabel}

Sebelum dilakukan pengambilan data, terlebih dahulu peneliti mendefinisikan variabel yang akan diteliti termasuk indikator dan skala pengukuran yang digunakan

JAS-PT

JURNAL ANALISIS SISTEM PENDIDIKAN TINGGI ISSN $2580-5339$ elSSN $2620-5718$ Volume 4 Nomor 1 JULI 2020 Hal 33 - 46 
Tabel 1. Definisi Operasional Variabel

\begin{tabular}{|c|c|c|c|}
\hline No & Variabel & Indikator & Skala \\
\hline 1. & $\begin{array}{l}\text { Orientasi Kepemimpinan (X1) adalah } \\
\text { perilaku dan strategi, sebagai hasil } \\
\text { kombinasi dari falsafah, } \\
\text { keterampilan, sifat, sikap, yang } \\
\text { sering diterapkan dari seorang } \\
\text { pemimpin ketika ia mencoba } \\
\text { mempengaruhi kinerja bawahannya } \\
\text { (Rorimpandey, 2013). }\end{array}$ & $\begin{array}{l}\text { 1. Kemampuan Mengambil } \\
\text { Keputusan } \\
\text { 2. Kemampuan Memotivasi } \\
\text { 3. Kemampuan Komunikasi } \\
\text { 4. Kemampuan Mengendalikan } \\
\text { Bawahan }\end{array}$ & Likert \\
\hline 2. & $\begin{array}{l}\text { Tingkat Penghargaan (X2) Tingkat } \\
\text { Penghargaan/apresiasi adalah salah } \\
\text { satunya ditunjukan dengan } \\
\text { pemberian kompensasi. Kompensasi } \\
\text { adalah segala bentuk pembayaran } \\
\text { atau apresiasi yang diberikan } \\
\text { kepada karyawan yang timbul akibat } \\
\text { pekerjaan mereka (Dessler, } 2015 \text { : } \\
302 \text { ) }\end{array}$ & $\begin{array}{l}\text { 1. Pemberian komisi yang } \\
\text { diterapkan manajemen } \\
\text { perusahaan cukupadil } \\
\text { 2. Perusahaan memberi bonus } \\
\text { jika mampu mencapai kinerja } \\
\text { yang diharapkan } \\
\text { 3. Pemberian penghargaan yang } \\
\text { sesusai dengan tanggung } \\
\text { jawab pekerjaan karyawan } \\
\text { 4. Promosi Jabatan yang diberikan } \\
\text { manajemen perusahaan } \\
\text { kepada karyawan }\end{array}$ & Likert \\
\hline 3. & $\begin{array}{l}\text { Loyalitas Karyawan (Y) Loyalitas } \\
\text { merupakan kesediaan karyawan } \\
\text { dengan seluruh kemampuan, } \\
\text { keterampilan, pikiran dan waktu } \\
\text { untuk ikut serta mencapai tujuan } \\
\text { perusahaan dan menyimpan rahasia } \\
\text { perusahaan serta tidak melakukan } \\
\text { tindakan-tindakan yang merugikan } \\
\text { perusahaan selama orang itu masih } \\
\text { berstatus sebagai karyawan. } \\
\text { (Robbins, 2014) }\end{array}$ & $\begin{array}{l}\text { 1. Tetap bertahan dalam } \\
\text { organisasi } \\
\text { 2. Bersedia bekerja lembur untuk } \\
\text { menyelesaikan pekerjaan. } \\
\text { 3. Menjaga rahasia bisnis } \\
\text { perusahaan. } \\
\text { 4. Mau mengikuti arahan atau } \\
\text { instruksi } \\
\text { 5. Tingkat kejujuran dalam } \\
\text { melaksanakan setiap tugas } \\
\text { yang diberikan }\end{array}$ & Likert \\
\hline
\end{tabular}

\section{Teknik Pengumpulan Data}

Dalam penulisan ini untuk mengumpulkan data yang diperlukan, penulis melakukan riset dengan menggunakan metode :

1. Observasi, merupakan salah teknik pengumpulan data yang mempunyai ciri yang spesifik bila dibandingkan dengan teknik yang lain, yaitu wawancara dan kuesioner. Pengambilan data yang dilakukan dengan cara pengamatan langsung ke Universitas Lancang Kuning Pekanbaru dengan tujuan meninjau permasalahan.

2. Dokumentasi. Pengambilan data yang dilakukan dengan cara meminta kepada perusahaan tentang data sekunder berupa jumlah karyawan, rata-rata insentif, serta laporan lain yang relevan dengan penelitian.

JAS-PT

JURNAL ANALISIS SISTEM PENDIDIKAN TINGG

ISSN $2580-5339$

elSSN $2620-5718$

Volume 4

Nomor 1

JULI 2020

Hal 33 - 46

FORUM DOSEN INDONESIA
3. Kuesioner. Menyebarkan kuesioner ini dimaksudkan untuk mendapatkan data deskritif guna menguji hipotesis serta untuk memperoleh data tersebut digunakan kuesioner yang bersifat tertutup, yaitu pernyataan yang dibuat sedemikian rupa hingga responden dibatasi dalam memberi jawaban kepada beberapa alternative saja dengan skala likert.

Pengukuran variabel dilakukan dengan skala Likert yang meggunakan metode scoring sebagai berikut: Angka 1 menunjukkan bahwa responden tidak mendukung terhadap 
pertanyaan yang diberikan. Sedangakan angka 5 menunjukkan bahwa responden mendukung terhadap pertanyaan yang diberikan.

Tabel 2. Penetapan Skor Atas Jawaban Responden

\begin{tabular}{|c|l|c|}
\hline No & \multicolumn{1}{|c|}{ Kategori } & Skor \\
\hline 1 & Sangat Setuju & 5 \\
\hline 2 & Setuju & 4 \\
\hline 3 & Ragu-Ragu & 3 \\
\hline 4 & Tidak setuju & 2 \\
\hline 5 & Sangat tidak setuju & 1 \\
\hline
\end{tabular}

\section{Metode Analisis Data}

\section{Analisis Statistik Deskriptif}

Analisis statistik deskriptif dalam suatu penelitian pada dasarnya merupakan proses transformasi data penelitian dalam bentuk tabulasi sehingga mudah dipahami dan diinterpretasikan. Tabulasi menyajikan ringkasan, pengaturan atau penyusunan data dalam bentuk tabel numerik dan grafik. Statistik deskriptif umumnya digunakan oleh peneliti untuk memberikan informasi mengenai karakteristik variabel penelitian yang utama dan data demografi responden. Analisis statistik deskriptif yang digunakan dalam penelitian ini adalah menggunakan tabel distribusi frekuensi yang menunjukkan nilai minimum, nilai maksimum, nilai rata-rata (mean) dan standar deviasi yang bertujuan untuk memberikan gambaran atau deskripsi mengenai variabel-variabel penelitian yang terdiri disiplin kerja, lingkungan kerja, budaya organisasi dan kinerja karyawan. Sedangkan untuk mendeskripsikan demografi responden yang terdiri dari jenis kelamin, lama bekerja, jabatan dan tingkat pendidikan digunakan tabel distribusi frekuensi dan persentase. Analisis deskriptif, digunakan untuk menggambarkan skor variabel $X$ dan variabel $Y$ serta kedudukannya dan menjawab tujuan penelitian yang bersifat deskriptif. Analisis ini dilakukan melalui tinjauan kontinum dan perbandingan rata-rata data sampel.

\section{Uji Kualitas Data}

Ketepatan pengujian suatu hipotesis sangat tergantung dari kualitas data yang dipakai dalam pengujian tersebut. Kualitas data penelitian ditentukan oleh kualitas instrumen yang digunakan untuk mengumpulkan data (Sugiyono, 2016 : 147). Uji kualitas data meliputi uji validitas dan uji reliabilitas. Untuk menentukan uji validitas dan reliabilitas, peneliti menggunakan perhitungan dengan bantuan SPSS (Statistical Product and Service Solution) for Windows ver 17 untuk memperoleh hasil yang terarah. Uji validitas dilakukan untuk mengetahui apakah suatu instrument alat ukur telah menjalankan fungsi ukurnya. Validitas menunjukkan ketepatan dan kecermatan alat ukur dalam melakukan fungsi ukurnya atau suatu skala pengukuran disebut valid bila ia melakukan apa yang seharusnya dilakukan dan mengukur apa yang seharusnya diukur, Uji validitas bertujuan mengetahui ketepatan dan kehandalan kuesioner yang mempunyai arti bahwa kuesioner mampu mengukur apa yang seharusnya diukur (Ghozali, 2013 : 52). Uji validitas dalam penelitian ini dilakukan menggunakan rumus Product Moment Pearson dengan bantuan SPSS (Statistical Product and Service Solution) for Windows ver 17. Suatu kuesioner dikatakan valid apabila memenuhi kriteria sebagai berikut: Hasil $r$ hitung $>r$ tabel dan atau Nilai signifikansi $(p)<0,05$

Pengujian reliabilitas berkaitan dengan masalah adanya kepercayaan terhadap instrument. Suatu instrument dapat memiliki tingkat kepercayaan yang tinggi (konsisten) jika hasil dari pengujian instrument tersebut menunjukkan hasil yang tetap. Dengan demikian, masalah realibilitas dilakukan untuk mengetahui tingkat kestabilan suatu alat ukur. Hasil pengukuran dapat dipercaya apabila digunakan dalam beberapa kali pengukuran terhadap kelompok subjek yang sama diperoleh dasil relative sama, selama aspek yang diukur dalam diri subjek tidak

JAS-PT

JURNAL ANALISIS SISTEM PENDIDIKAN TINGGI ISSN $2580-5339$ eISSN $2620-5718$

Volume 4

Nomor 1

JULI 2020

Hal $33-46$

FORUM DOSEN INDONESIA 
berubah. Cara mengukur realibilitas yang paling umum adalah dengan menggunakan koefisien alpha. Koefisien alpha bisa diukur dengan menggunakan uji statistik Cronbach Alpha. Suatu variabel dikatakan reliable jika memberikan nilai cronbach Alpha > 0,6 (Ghozali, $2013: 47$ ). Uji reliabilitas juga dilakukan dengan bantuan software SPSS (Statistical Product and Service Solution) for Windows ver 17.

Berdasarkan kaidah penelitian, maka kuesioner atau angket atau instrumen yang digunakan sebagai alat ukur terhadap variabel tersebut harus memenuhi kriteria Valid dan Reliabel, maka perlu dilakukan pengujian seperlunya. Pengujian terhadap validitas dimaksudkan untuk memeriksa apakah butir-butir dalam instrumen tersebut benarbenar mampu memberikan ukuran (data) sesuai (tepat) seperti yang dikehendaki peneliti. Pengujian terhadap validitas akan digunakan uji $t$ untuk koefisien korelasi sederhana (Pearson) antara skor pada setiap butir dengan skor total dari butir-butir tersebut. Suatu butir dinyatakan valid jika taraf signifikansi dari koefisien korelasi Pearson tersebut $\leq 0,03$. Sedangkan uji reliabilitas terhadap instrumen dimaksudkan untuk mengetahui apakan angket tersebut benar-benar konsisten (ajeg) jika digunakan untuk mengukur hal yang sama berulang-ulang. Pengujian terhadap reliabilitas angket dilakukan dengan menggunakan Koefisien Alpha Cronbach yang berbasis harga varians. Suatu angket dinyatakan reliabel jika harga Koefisien Alpha Cronbach > 0,6. Untuk mengetahui secara lebih terperinci hasil uji validitas dan reliabilitas terhadap item pernyataan kepemimpinan transformasional yang terdapat pada kuesioner penelitian dapat dilihat pada tabel berikut :

Tabel 3 Validitas dan Reliabilitas Orientasi Kepemimpinan (X1)

\begin{tabular}{|c|c|c|c|}
\hline Item Pertanyaan & Total Correlation & Cronbach's Alpha & Keterangan \\
\hline X.1 & .679 & .918 & Valid \& Reliabel \\
X.2 & .865 & .854 & Valid \& Reliabel \\
X.3 & .818 & .872 & Valid \& Reliabel \\
X.4 & .816 & .873 & Valid \& Reliabel \\
\hline \multicolumn{3}{|l}{} \\
\hline
\end{tabular}

Sumber : Data Primer Diolah Penelitian

Sebagaimana tergambar pada tabel diatas, besarnya korelasi product moment terkoreksi masing-masing item pertanyaan lebih besar dari 0,3 yang berarti signifikan. Dengan dapat disimpulkan bahwa item pertanyaan dalam kuesioner varibel Orirentasi Kepemimpinan (X1) adalah Valid. Hasil perhitungan koefisien reliabilitas Alpha Cronbach's diketahui pula memiliki nilai sebesar 0,908, sedangkan nilai batas (nilai kritis) sebesar 0,60. Dapat disimpulan bahwa kuesioner variabel Orientasi Kepemimpinan adalah reliabel dan layak digunakan. Hasil validitas dan reliabilitas terhadap item pertanyaan untuk variabel Penghargaan (X2) tergambar sebagai berikut

Tabel 4 Validitas dan Reliabilitas Variabel Penghargaan (X2)

JAS-PT

JURNAL ANAUISIS SISTEM PENDIDIKAN TINGG

ISSN $2580-5339$

eISSN $2620-5718$

Volume 4

Nomor 1

JULI 2020

Hal 33 - 46

FORUM DOSEN INDONESIA

\begin{tabular}{|c|c|c|c|}
\hline Item Pertanyaan & Total Correlation & Cronbach's Alpha & Keterangan \\
\hline X.1 & .556 & .696 & Valid \& Reliabel \\
X.2 & .596 & .681 & Valid \& Reliabel \\
X.3 & .634 & .661 & Valid \& Reliabel \\
X.4 & .468 & .740 & Valid \& Reliabel \\
\hline Cronbach's Alpha $=0,755$ & \multicolumn{3}{|l}{} \\
\hline
\end{tabular}

Sumber : Data Primer Diolah Penelitian

Sebagaimana tergambar pada tabel diatas, besarnya korelasi product moment terkoreksi masing-masing item pertanyaan lebih besar dari 0,3 yang berarti signifikan. Dengan dapat disimpulkan bahwa item pertanyaan dalam kuesioner varibel Penghargaan (X2) adalah Valid. Hasil perhitungan koefisien reliabilitas Alpha 
Cronbach's diketahui pula memiliki nilai sebesar 0,755 , sedangkan nilai batas (nilai kritis) sebesar 0,60. Dapat disimpulan bahwa kuesioner variabel Penghargaan adalah reliabel dan layak digunakan. Hasil validitas dan reliabilitas terhadap item pertanyaan untuk variabel Loyalitas Karyawan $(\mathrm{Y})$ tergambar sebagai berikut :

Tabel 5 Validitas dan Reliabilitas Variabel Loyalitas Karyawan (Y)

\begin{tabular}{|c|c|c|c|}
\hline Item Pertanyaan & Total Correlation & Cronbach's Alpha & Keterangan \\
\hline Y.1 & .681 & .899 & Valid \& Reliabel \\
Y.2 & .838 & .843 & Valid \& Reliabel \\
Y.3 & .785 & .863 & Valid \& Reliabel \\
Y.4 & .794 & .860 & Valid \& Reliabel \\
\hline \multicolumn{2}{|l}{} \\
\hline
\end{tabular}

Sumber : Data Primer Diolah Penelitian

Sebagaimana tergambar pada tabel diatas, besarnya korelasi product moment terkoreksi masing-masing item pertanyaan lebih besar dari 0,3 yang berarti signifikan. Dengan dapat disimpulkan bahwa item pertanyaan dalam kuesioner varibel Orirentasi Kepemimpinan (X1) adalah Valid. Hasil perhitungan koefisien reliabilitas Alpha Cronbach's diketahui pula memiliki nilai sebesar 0,897, sedangkan nilai batas (nilai kritis) sebesar 0,60. Dapat disimpulan bahwa kuesioner variabel Orientasi Kepemimpinan adalah reliabel dan layak digunakan.

Sebelum melakukan pengujian hipotesis dengan menggunakan analisis regresi berganda, maka diperlukan pengujian asumsi klasik. Ada empat asumsi yang terpenting sebagai syarat penggunaan metode regresi. Asumsi tersebut adalah asumsi normalitas, multikolinearitas dan heterokedastisitas. Pengujian ini perlu dilakukan karena adanya konsekuensi yang mungkin terjadi jika asumsi tidak bisa dipenuhi._Uji normalitas bertujuan untuk menilai sebaran data pada sebuah kelompok data atau variabel, apakah sebaran data tersebut berdistribusi normal ataukah tidak. Uji Normalitas bertujuan untuk menguji apakah dalam model regresi, variabel pengganggu atau residual memiliki distribusi normal. Seperti diketahui bahwa uji $t$ dan $F$ mengasumsikan bahwa nilai residual mengikuti distribusi normal. Kalau asumsi ini dilanggar maka uji statistik menjadi tidak valid untuk jumlah sampel kecil. Ada dua cara untuk mendeteksi apakah residual berdistribusi normal atau tidak yaitu dengan analisis grafik dan uji statistik. Pengujian dengan menggunakan uji statistik One Sample Kolmogorov-Smirnov Test (K-S). Jika nilai probabilitas signifikansi K-S lebih besar dari 0.05, maka data berdistribusi normal (Ghozali, $2013: 29$ ).

Uji heteroskedatisitas bertujuan untuk menguji apakah dalam model regresi terjadi ketidaksamaan varian dari residual satu pengamatan ke pengamatan lain, jika varian dari residual satu pengamatan ke pengamatan lain tetap, maka disebut homoskedatisitas. Namun jika berbeda maka disebut heteroskedatisitas. Model regresi yang baik adalah homoskedatisitas. Uji yang digunakan adalah uji glejser dimana uji ini dilakukan dengan cara meregresikan nilai mutlak residual terhadap seluruh variabel bebas. Apabila nilai $p$-value pada hasil uji t terdapat koefisien regresi kecil dari nilai 0,05 maka nilai residual terjadi gejala heteroskedatisitas. Sedangkan apabila nilai $p$ value pada hasil uji t terdapat koefisien regresi lebih besar dari nilai 0,05 maka nilai residual tidak terjadi gejala heteroskedatisitas.

Menurut (Ghozali, 2013 : 105), uji multikolinearitas bertujuan untuk menguji apakah dalam model regresi ditemukan adanya korelasi antar variabel independen. Model regresi yang baik seharusnya tidak terjadi korelasi diantara variabel bebas. Untuk mendekteksi multikolinearitas dapat melihat nilai tolerance dan Variance Inflation Factor (VIF). Apabila tidak terdapat variabel bebas yang memiliki nilai torelance kurang dari

JAS-PT

JURNAL ANALISIS SISTEM PENDIDIKAN TINGGI ISSN $2580-5339$ eISSN $2620-5718$

Volume 4

Nomor 1

JULI 2020

Hal $33-46$

FORUM DOSEN INDONESIA 
0,10 atau VIF lebih dari 10, maka tidak ada multikolinearitas antar variabel bebas dalam model regresi. Sebaliknya jika terdapat variabel bebas yang memiliki nilai tolerance kurang dari 0,10 atau VIF lebih dari 10, maka terjadi gangguan multikolinearitas pada penelitian.

Pengujian normalitas residual dapat dilihat dari grafik normal P-P plot sebagaimana tergambar berikut ini : Normal P-P Plot of Regression Standardized

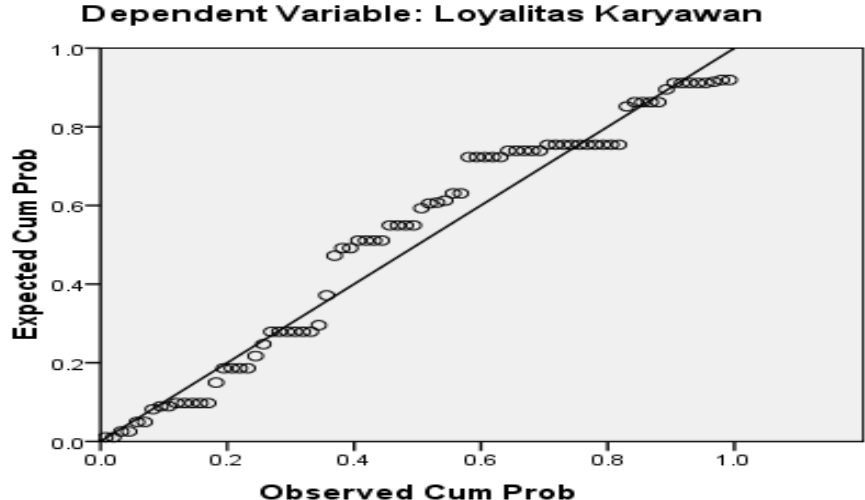

Gambar 1 Pengujian normalitas residual dapat dilihat dari grafik normal P-P plot

Dari tampilan grafik normal plot pada gambar diatas, terlihat titik-titik disekitar berada dalam garis lurus melintang. Dengan demikian dapat disimpulkan bahwa nilai residual mengikuti distribusi normal. Selain itu dapat pula dibuktikan pula dengan uji statistik Kolmogorov-Smirnov dimana nilai keseluruhan variabel asym Sig. (2-tailed) >0,05. Dengan demikian semua data memenuhi asumsi kenormalan.

Model regresi yang baik seharusnya tidak terjadi korelasi diantara variabel bebas. Multikolearitas dapat diuji melalui nilai toleransi dengan faktor variasi inlasi (Variance inflation Factor/VIF). Batas toleransi a $=5 \%$, apabila VIF $<10$ maka model tersebut tidak terdapat multikolearitas. Hasil pengujian untuk seluruh variabel dapat dilihat pada tabel berikut :

Tabel 6 Hasil Uji Multikolinieritas

\begin{tabular}{|ll|c|c|}
\hline \multirow{2}{*}{ Model } & \multicolumn{2}{|c|}{ Coefficients $^{\text {C }}$} \\
\cline { 3 - 4 } & \multicolumn{2}{|c|}{ Collinearity Statistics } \\
\hline 1 & (Constant) & Tolerance & VIF \\
& Orientasi Kepemimpinan &, 292 & 3,421 \\
& Penghargaan &, 292 & 3,421 \\
\hline
\end{tabular}

a. Dependent Variable: Loyalitas Karyawan

Dari tabel di atas menunjukkan bahwa angka VIF $<10$, artinya seluruh variabel terbebas dari unsur multikolinearitas. Dengan demikian asumsi tidak adanya multikolinearitas sudah terpenuhi.

Pengujian dilakukan untuk mengetahui ada tidaknya penyimpangan asumsi klasik heteroskedastisitas, yaitu adanya ketidaksamaan varian dari residual untuk semua

JAS-PT

JURNAL ANAUISIS SISTEM PENDIDIKAN TINGG

ISSN $2580-5339$

eISSN $2620-5718$

Volume 4

Nomor 1

JULI 2020

Hal $33-46$

FORUM DOSEN INDONESIA pengamatan pada model regresi. Pengujian ada tidaknya sifat heteroskedastisitas pada setiap variabel bebas menggunakan grafik Scatterplot .

Dari grafik scatterplot diatas menunjukkan bahwa tidak terlihat pola yang jelas serta titik-titik yang menyebar diatas dan dibawah angka pada sumbu Y. Maka dapat disimpulkan bahwa instrumen yang digunakan pada semua variabel, bebas dari heteroskedastisitas dan layak untuk dipakai. 


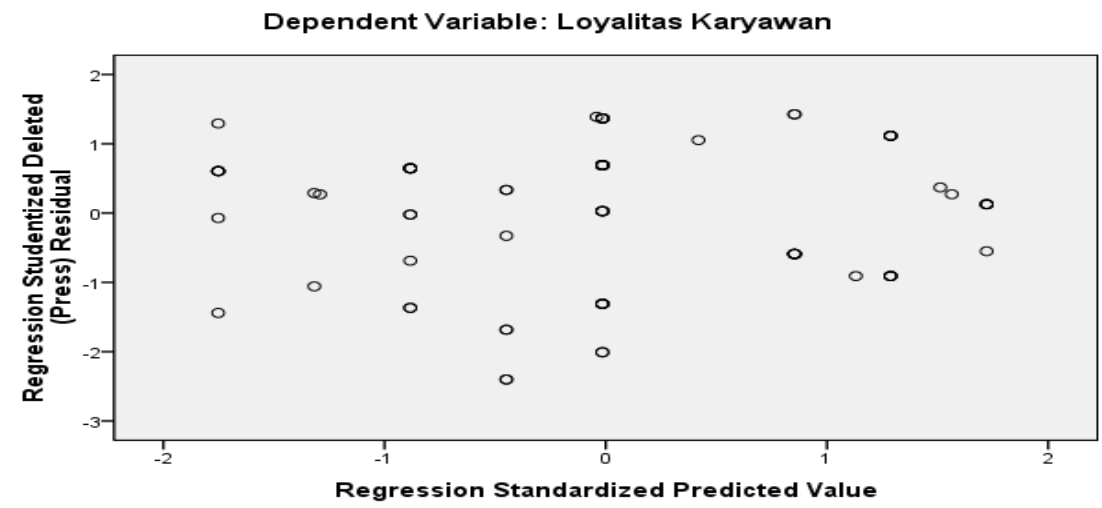

Gambar 2 Pengujian ada tidaknya sifat heteroskedastisitas pada setiap variabel bebas

\section{Uji Hipotesis} menggunakan grafik Scatterplot

Untuk menguji hipotesis dalam penelitian ini menggunakan analisis linier berganda. Analisis regresi linier berganda digunakan untuk mengetahui pengaruh antara dua atau lebih variabel independen dengan satu variabel dependen. Perhitungan analisis regresi linier berganda pada penelitian ini diuji dengan menggunakan software SPSS (Statistical Product and Service Solution) for Windows ver 17. Pengujian hipotesis dalam penelitian ini diuji dengan menggunakan nilai uji Standardized Coefficients. Orientasi kepemimpinan berpengaruh positif terhadap penghargaan. Pengaruh tersebut adalah positif dan signifikan dengan melihat nilai t-hitung dan sig 0,00 lebih kecil dari a 0,000 . Uji ini digunakan untuk mengetahui apakah variabel independen secara parsial berpengaruh terhadap variabel dependen

Penelitian ini mempunyai lima hipotesis yang diuji dengan menggunakan analisis regresi linier berganda yaitu sebagai berikut:

Hipotesis pertama $(\mathrm{H} 1)$ dari penelitian ini adalah Diduga Pengaruh Orientasi Kepemimpinan terhadap Loyalitas Karyawan, hipotesis penelitian yang akan diuji yaitu:

HO : Orientasi Kepemimpinan tidak berpengaruh terhadap Loyalitas Karyawan.

H1 : Orientasi Kepemimpinan berpengaruh terhadap Loyalitas Karyawan.

Hipotesis kedua $(\mathrm{H} 2)$ dari penelitian ini adalah Diduga Pengaruh Tingkat Penghargaan terhadap Loyalitas Karyawan, hipotesis penelitian yang akan diuji yaitu:

$\mathrm{HO}$ : Tingkat Penghargaan tidak berpengaruh terhadap Loyalitas Karyawan.

$\mathrm{H} 1$ : Tingkat Penghargaan berpengaruh terhadap Loyalitas Karyawan.

Persamaan regresi dalam penelitian ini adalah sebagai berikut:

$$
Y=a+b 1 X 1+b 2 X 2
$$

Keterangan :

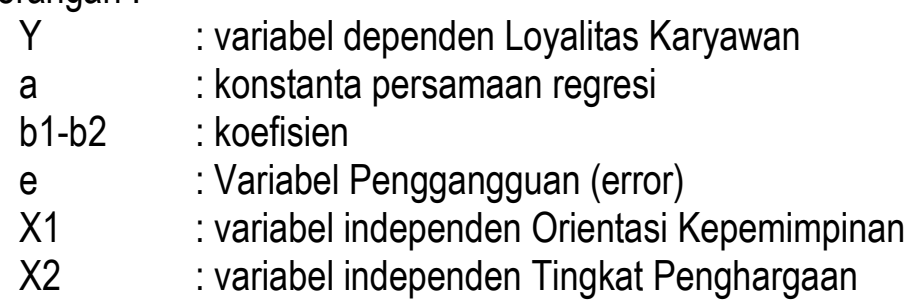

\section{Uji Determinasi $\left(\mathbf{R}^{2}\right)$}

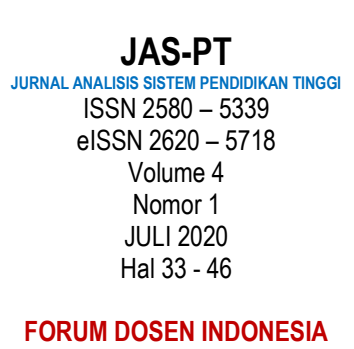

FORUM DOSEN INDONESIA 
Koefisien determinasi (KD) digunakan untuk menguji goodness-fit dari model regresi. Nilai koefisien determinasi adalah untuk melihat seberapa besar variabel-variabel independen secara bersama mampu memberikan penjelasan mengenai variabel independen. Dimana nilai $\mathrm{R}^{2}$ yang semakin tinggi menjelaskan bahwa variabel independen semakin baik kemampuannya dalam menjelaskan variabel dependen pada penelitian. Semakin kecil nilai $\mathrm{R}^{2}$ berarti semakin sedikit kemampuan variabel-variabel independen untuk menjelaskan variabel dependen pada penelitian. Hal-hal yang perlu diperhatikan mengenai koefisien determinasi adalah sebagai berikut:

Nilai $R^{2}$ harus berkisar 0 sampai 1

Bila $\mathrm{R}^{2}=1$ berarti terjadi kecocokan sempurna dari variabel independen menjelaskan variabel dependen.

Bila $R^{2}=0$ berarti tidak ada hubungan sama sekali antara variabel independen terhadap variabel dependen

\section{HASIL DAN PEMBAHASAN}

\section{Karakteristik Responden}

Pengolahan data mengenai profil responden dimaksudkan untuk mengetahui gambaran umum responden dari segi jenis kelamin, pendidikan dan pengalaman kerja. Dari sejumlah responden sebanyak 80 orang melalui kuisioner diperoleh hasil sebagai berikut :

Tabel 7 Sebaran Responden Berdasarkan Jenis Kelamin

\begin{tabular}{|c|ll|c|c|}
\hline No & Jenis Kelamin & Jumlah & Persentase (\%) \\
\hline 1 & Pria & 48 & 60 \\
2 & Wanita & & 32 & 40 \\
\hline \multicolumn{2}{|c|}{ Total } & 80 & 100 \\
\hline
\end{tabular}

Sumber : Data Primer Diolah

Berdasarkan tabel 7 diatas dapat diketahui bahwa komposisi responden berdasarkan jenis kelamin lebih dominan pria bila dibandingkan dengan wanita Komposisi pria sebesar $60 \%$ sedangkan wanita hanya $40 \%$.

Tabel 8 Responden Berdasarkan Pengalaman Kerja

\begin{tabular}{|c|c|c|c|c|}
\hline No. & Masa Kerja (Thn) & Kategori & Jumlah & Persentase \\
\hline 1 & $<5$ & Rendah & 28 & 35 \\
2 & $\geq 5-10$ & Sedang & 42 & 52,5 \\
3 & $>10$ & Tinggi & 10 & 12,5 \\
\hline \multicolumn{3}{|c|}{ Total } & 80 & 100 \\
\hline
\end{tabular}

Sumber : Data Primer Diolah

Berdasarkan tabel 8 diatas diketahui bahwa responden yang paling dominan dengan masa kerja 5 sampai 10 tahun sebesar $52,5 \%$. Sisanya dengan masa kerja 10 tahun sebesar $12,5 \%$ dan masa kerja 5 tahun sebesar 35\%. Hal ini menunjukkan bawa mayoritas responden memiliki pengalaman kerja yang memadai. Namun masih banyak pula responden yang memiliki pengalaman yang rendah.

JAS-PT

JURNAL ANALISIS SISTEM PENDIDIKAN TINGGI

ISSN $2580-5339$ eISSN $2620-5718$

Volume 4

Nomor 1

JULI 2020

Hal 33 - 46

FORUM DOSEN INDONESIA

\section{Persepsi Responden Atas Indikator Orientasi Kepemimpinan (X1)}

Definisi dari kepemimpinan telah mengalami perubahan akan perkembangan dan pergeseran. Dalam era lama orientasi kepemimpinan diartikan sebagai gaya kemampuan dan kesiapan yang dimiliki seseorang untuk mempengaruhi orang lain, dengan memotivasi, menggerakkan, mengarahkan, mengajak, menuntun dan jika perlu memaksa mereka untuk melakukan atau tidak melakukan sesuatu. Dari jawaban 
responden terhadap orientasi kepemimpinan diperoleh hasil sebagaimana tergambar pada tabel berikut :

Tabel 9 Tanggapan Responden Terhadap Orientasi Kepemimpinan

\begin{tabular}{|c|c|c|c|c|c|c|c|}
\hline No. & Indikator Pertanyaan & $\begin{array}{l}\text { Sangat } \\
\text { Setuju }\end{array}$ & Setuju & $\begin{array}{l}\text { Cukup } \\
\text { setuju }\end{array}$ & $\begin{array}{l}\text { Tidak } \\
\text { Setuju }\end{array}$ & $\begin{array}{l}\text { Sgt tdk } \\
\text { Setuju }\end{array}$ & \multirow{2}{*}{$\begin{array}{c}\text { Rata- } \\
\text { rata }\end{array}$} \\
\hline & & 5 & 4 & 3 & 2 & 1 & \\
\hline 1 & $\begin{array}{l}\text { Kemampuan Mengambil } \\
\text { Keputusan }\end{array}$ & 9 & 49 & 22 & 0 & 0 & 3,83 \\
\hline 2 & Kemampuan Memotivasi & 24 & 40 & 16 & 0 & 0 & 4,1 \\
\hline 3 & Kemampuan Komunikasi & 22 & 43 & 15 & 0 & 0 & 4,08 \\
\hline 4 & $\begin{array}{l}\text { Kemampuan Mengendalikan } \\
\text { Bawahan }\end{array}$ & 17 & 48 & 15 & 0 & 0 & 4,03 \\
\hline
\end{tabular}

Sumber : Data Primer Diolah

Persepsi Responden atas Indikator Penghargaan (X2)

Tingkat Penghargaan/apresiasi salah satunya ditunjukan dengan pemberian kompensasi. Kompensasi merupakan salah satu fungsi yang penting dalam manajemen sumber daya manusia (MSDM). Karena kompensasi merupakan salah satu aspek yang paling sensitif di dalam hubungan kerja. Kasus yang terjadi dalam hubungan kerja mengandung masalah kompensasi dan berbagai segi yang terkait, seperti tunjangan, kenaikan kompensasi, struktur kompensasi dan skala kompensasi. Kompensasi meliputi bentuk pembayaran tunai langsung, pembayaran tidak langsung dalam bentuk manfaat karyawan, dan insentif untuk memotivasi karyawan agar bekerja keras untuk mencapai produktivitas yang semakin tinggi. Jika dikelola dengan baik, maka dengan kompensasi ini dapat membantu perusahaan untuk mencapai produktivitas yang semakin tinggi bagi karyawannya. Dari jawaban responden terhadap penghargaan diperoleh hasil sebagaimana tergambar pada tabel berikut :

Tabel 10 Tanggapan Responden Terhadap Penghargaan

\begin{tabular}{|c|l|c|c|c|c|c|c|}
\hline No & \multicolumn{1}{|c|}{ Indikator Pertanyaan } & SS & S & CS & TS & STS & $\begin{array}{c}\text { Rata- } \\
\text { rata }\end{array}$ \\
\cline { 2 - 9 } & \multicolumn{1}{|c|}{$\begin{array}{l}\text { Pemberian komisi yang diterapkan manajemen } \\
\text { perusahaan cukup adil }\end{array}$} & 17 & 47 & 9 & 0 & 0 & 4,08 \\
\hline 2 & $\begin{array}{l}\text { Perusahaan memberi bonus jika mampu } \\
\text { mencapai kinerja yang diharapkan }\end{array}$ & 6 & 57 & 17 & 0 & 0 & 3,86 \\
\hline 3 & $\begin{array}{l}\text { Pemberian penghargaan yang sesusai dengan } \\
\text { tanggung jawab pekerjaan karyawan }\end{array}$ & 29 & 33 & 18 & 0 & 0 & 4,14 \\
\hline 4 & $\begin{array}{l}\text { Promosi Jabatan yang diberikan manajemen } \\
\text { perusahaan kepada karyawan }\end{array}$ & 7 & 57 & 16 & 0 & 0 & 3,89 \\
\hline
\end{tabular}

Sumber : Data Primer Diolah

\section{Persepsi Responden atas Indikator Loyalitas Karyawan}

Loyalitas merupakan kesediaan karyawan dengan seluruh kemampuan, keterampilan, pikiran dan waktu untuk ikut serta mencapai tujuan perusahaan dan menyimpan rahasia perusahaan serta tidak melakukan tindakan-tindakan yang merugikan perusahaan selama orang itu masih berstatus sebagai karyawan. Loyalitas karyawan dapat tercipta dari beberapa segi konstruksi, yang ditandai dengan identifikasi seorang karyawan dengan tujuan perusahaan dan dengan etika kerja. loyalitas dari seorang karyawan dapat ditunjukan melalui perasaan seorang individu untuk bergabung bersama perusahaan dan menjadi rekan kerja, keinginan untuk membantu pimpinan perusahaan, bertindak sesuai etika kerja dan profesionalisme dan setia ke perusahaan apabila sedang kritis. Dari jawaban responden terhadap loyalitas karyawan diperoleh hasil sebagaimana tergambar pada tabel berikut :

JAS-PT

JURNAL ANALISIS SISTEM PENDIDIKAN TINGGI ISSN $2580-5339$ eISSN $2620-5718$

Volume 4

Nomor 1

JULI 2020

Hal 33 - 46

FORUM DOSEN INDONESIA 
Tabel 11 Tanggapan Responden Terhadap Loyalitas Karyawan

\begin{tabular}{|c|l|c|c|c|c|c|c|}
\hline \multirow{2}{*}{ No. } & \multicolumn{1}{|c|}{ Indikator Pertanyaan } & SS & S & CS & TS & STS & \multirow{2}{*}{ Rata-rata } \\
\cline { 3 - 8 } & & 5 & 4 & 3 & 2 & 1 & \\
\hline 1 & Tetap bertahan dalam organisasi & 7 & 48 & 25 & 0 & 0 & 3,78 \\
\hline 2 & $\begin{array}{l}\text { Bersedia bekerja lembur untuk } \\
\text { menyelesaikan pekerjaan. }\end{array}$ & 21 & 40 & 19 & 0 & 0 & 4,03 \\
\hline 3 & Menjaga rahasia bisnis perusahaan. & 29 & 33 & 18 & 0 & 0 & 4,04 \\
\hline 4 & Mau mengikuti arahan atau instruksi & 19 & 45 & 16 & 0 & 0 & 3,96 \\
\hline
\end{tabular}

Sumber : Data Primer Diolah (lampiran

\section{Analisis Regresi Berganda}

Hasil deskripsi data dari skor rata-rata jawaban responden belum dapat dipergunakan sebagai dasar penarikan kesimpulan tentang pengaruh disiplin dan motivasi terhadap loyalitas karyawan. Untuk itu diperlukan serangkaian pengujian terhadap hipotesis, sebagai berikut :

Tabel 12 Hasil Uji statistik F

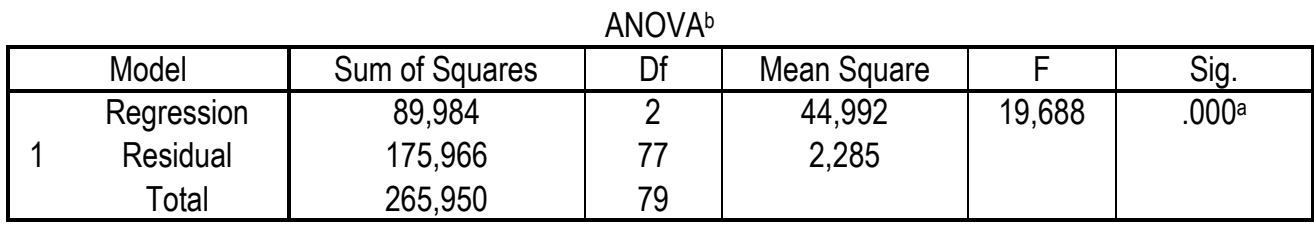

a. Predictors: (Constant), Penghargaan, Orientasi Kepemimpinan

b. Dependent Variable: Loyalitas Karyawan

Dari tabel diatas dapat diketahui bahwa model yang digunakan mempunyai nilai $\mathrm{F}$ hitung sebesar 19,688 > F-tabel sebesar 3,441, dengan uji sig 0,000, lebih kecil dari alfa a 0,05 sehingga pengujian hipotesis ini terbukti maka Ha diterima dan $\mathrm{Ho}$ ditolak .

Hasil regresi linier berganda berdasarkan Data Primer Diolah SPSS tergambar sebagai berikut :

\section{Tabel 13 Hasil Regresi Berganda}

Coefficients $^{a}$

\begin{tabular}{|c|c|c|c|c|c|c|}
\hline \multirow{2}{*}{\multicolumn{2}{|c|}{ Model }} & \multicolumn{2}{|c|}{ Unstandardized Coefficients } & Standardized Coefficients & \multirow{2}{*}{$t$} & \multirow{2}{*}{ Sig. } \\
\hline & & $B$ & Std. Error & Beta & & \\
\hline \multirow{3}{*}{1} & (Constant) & 8,545 & 1,239 & & 6,899 &, 000 \\
\hline & $\begin{array}{l}\text { Orientasi } \\
\text { Kenemimninan }\end{array}$ & ,435 & ,135 & ,552 & 3,221 & ,002 \\
\hline & Penghargaan & ,279 & ,138 & 035 & ,202 &, 040 \\
\hline
\end{tabular}

a. Dependent Variable:

Loyalitas Karyawan

Berdasarkan table coefficients dapat dilihat hubungan masing-masing variable secara langsung dengan melihat nilai Standardized Coefficients sebesar 0,552 dan 0,035 atau dengan persamaan

$$
Y=8,545+0,435(X 1)+0,279(X 2)
$$

Dari persamaan regresi linier berganda diatas dapat dijelaskan secara terperinci:

JAS-PT

JURNAL ANALISIS SISTEM PENDIDIKAN TINGGI

ISSN $2580-5339$

eISSN $2620-5718$

Volume 4

Nomor 1

JULI 2020

Hal 33 - 46

FORUM DOSEN INDONESIA a. Nilai konstanta sebesar 8,545 , artinya apabila orientasi kepemimpinan dan penghargaan dalam keadaan konstan (tetap) maka loyalitas karyawan bernilai 8,545 satuan.

b. Koefisien orientasi kepemimpinan (b1) sebesar 0,435 , artinya apabila orientasi kepemimpinan ditingkatkan sebesar 1 satuan sedangkan penghargaan dalam keadaan konstan (tetap), maka loyalitas karyawan meningkat atau sebesar 0,435 satuan. Dengan demikian orientasi kepemimpinan berpengaruh positive terhadap loyalitas karyawan. 
c. Koefisien penghargaan (b2) sebesar 0,279, artinya apabila penghargaan ditingkatkan sebesar 1 satuan sedangkan orientasi kepemimpinan dalam keadaan konstan (tetap), maka dapat loyalitas karyawan meningkat atau sebesar 0,279 satuan. Dengan demikian dapat dikatakan bahwa penghargaan berpengaruh positive terhadap loyalitas karyawan.

d. Variabel dominan berpengaruh terhadap loyalitas karyawan adalah orientasi kepemimpinan dengan kontribusi sebesar 43,5\%.

Kemudian berdasarkan hasil pengujian untuk melihat pengaruh orientasi kepemimpinan terhadap penghargaan secara langsung (Parsial).

Tabel 14 Hasil Secara parsial

Coefficients $^{a}$

\begin{tabular}{|c|c|c|c|c|c|}
\hline \multirow{2}{*}{ Model } & \multicolumn{2}{|c|}{ Unstandardized Coefficients } & Standardized Coefficients & \multirow{2}{*}{$t$} & \multirow{2}{*}{ Sig. } \\
\hline & $B$ & Std. Error & Beta & & \\
\hline $1 \quad$ (Constant) & 8,618 & 1,178 & & 7,316 &, 000 \\
\hline $\begin{array}{l}\text { Orientasi } \\
\text { Kepemimpinan }\end{array}$ & ,458 & 073 &, 581 & 6,311 &, 000 \\
\hline
\end{tabular}

a. Dependent Variable: Penghargaan

Dengan nilai Standardized Coefficients 0,458 ini artinya jika orientasi kepemimpinan ditingkatkan sebesar satu satuan maka penghargaan meningkat sebesar 0,458 satuan, orientasi kepemimpinan berpengaruh positif terhadap penghargaan. Pengaruh tersebut adalah positif dan signifikan dengan melihat nilai t-hitung sebesar 6,311 dengan sig 0,00 lebih kecil dari a 0,000.

\section{Pengujian Koefisien Determinasi $\left(\mathrm{R}^{2}\right)$}

Koefisien determinasi $\left(R^{2}\right)$ pada intinya mengukur seberapa jauh kemampuan model dalam menerangkan variasi variabel independen. Dari hasil analisis regresi linier berganda diperoleh hasil sebagai berikut :

Tabel 15 Hasil Pengujian Koefisien Determinasi

Model Summaryb

\begin{tabular}{|c|c|c|c|c|}
\hline Model & $\mathrm{R}$ & $\mathrm{R}$ Square & Adjusted R Square & Std. Error of the Estimate \\
\hline 1 & $.582^{\mathrm{a}}$ &, 338 &, 321 & 1,51171 \\
\hline
\end{tabular}

a. Predictors: (Constant), Penghargaan, Orientasi Kepemimpinan

b. Dependent Variable: Loyalitas Karyawan

Dari tabel diatas dketahui besarnya Adjusted $R$. Square adalah 0,321. Hal ini berarti $32,1 \%$ variabel Loyalitas Karyawan $(Y)$ yang dapat dijelaskan oleh variabel Orientasi Kepemimpinan (X1) dan Penghargaan (X2). Sedangkan sisanya 67,9 \% dijelaskan oleh variabel lain diluar model penelitian ini.

\section{PENUTUP}

Berdasarkan hasil pembahasan diperoleh kesimpulan sebagai berikut :

1. Pengaruh Secara Simultan

Pengaruh Orientasi Kepemimpinan dan Penghargaan secara simultan (bersama-sama) terhadap Loyalitas Karyawan ditunjukkan dari hasil analisis statistik Koefisien determinasi $\left(\mathrm{R}^{2}\right)$ dengan besarnya Adjusted $R$ Square 0,321 atau 32,1\%. Berarti kontribusi orientasi kepemimpinan dan penghargaan secara simultan terhadap loyalitas karyawan sebesar $32,1 \%$, sedangkan sisanya $67,9 \%$ lagi dijelaskan oleh variabel lain diluar variabel penelitian. Kombinasi dari Orientasi Kepemimpinan dan Penghargaan yang baik dapat menigkatkan Loyalitas Karyawan. Demikian pula sebaliknya,

JAS-PT

JURNAL ANALISIS SISTEM PENDIDIKAN TINGG ISSN $2580-5339$ elSSN $2620-5718$

Volume 4

Nomor 1

JULI 2020

Hal 33 - 46

FORUM DOSEN INDONESIA 
kombinasi Orientasi Kepemimpinan dan Penghargaan yang kurang baik dapat menurunkan Loyalitas Karyawan.

\section{Pengaruh Secara Parsial}

Analisis regresi berganda menunjukkan bahwa pengawasan mempunyai pengaruh terhadap disiplin kerja karyawan sebesar 0,435 , berarti apabila orientasi kepemimpinan ditingkatkan sebesar 1 satuan maka akan meningkatkan loyalitas kerja sebesar 0,435 satuan. Sedangkan penghargaan mempunyai pengaruh terhadap loyalitas karyawan sebesar 0,279, berarti apabila penghargaan ditingkatkan sebesar 1 satuan maka akan meningkatkan loyalitas karyawan sebesar 0,279 satuan. Orientasi kepemimpinan merupakan faktor dominan berpengaruh terhadap loyalitas karyawan pada Universitas Lancang Kuning Pekanbaru. Loyalitas pada umumnya mencakup baik aspek kualitatif maupun kuantitatif dari pelaksanaan pekerjaan, peningkatan terhadap kepemimpinan dan penghargaan dapat meningkatkan loyalitas karyawan, sebaliknya penurunan terhadap orientasi kepemimpinan dan penghargaan dapat menurunkan loyalitas karyawan.

\section{DAFTAR PUSTAKA}

Antoncic, B. 2016. Employee loyalty and its impact on firm growth. International Journal of Management \& Information Systems. 15(1), 81-88.

Bungin, Burhan. 2015, Metodologi Penelitian Kualitatif: Depok, Rajagrafindo Pustaka.

Dessler, Gary. 2015. Manajemen Sumber Daya Manusia. Jakarta: Salemba Empat.

Ghozali, Imam. 2013. Aplikasi Analisis Multivariate dengan Program IBM SPSS 19, Semarang: Badan Penerbit Universitas Diponegoro

Hasibuan, Malayu S.P. 2016. "Manajemen Sumber Daya Manusia". Edisi Revisi. Jakarta: Penerbit PT Bumi Aksara.

Martiwi, R.T.2014. Faktor Penentu yang Mempengaruhi Loyalitas Kerja Karyawan. Daya Saing Jurnal Ekonomi Manajemen Sumber Daya, 13 (1), 44-52.

Marwansyah. 2016. Manajemen Sumber Daya Manusia, Edisi Dua. Cetakan keempat. Bandung : Alfabeta,CV

Robbins, Stephen P. dan Coulter, Mary. 2016. Manajemen, Edisi kesepuluh. Jakarta : Erlangga.

Sadili, Samsudin. 2014. Manajemen Sumber Daya Manusia. Jakarta : CV Pustaka Setia.

Siagian, P. Sondang. 2016. Teori dan Praktek Kepemimpinan. Jakarta : Rineka Cipta.

Sunyoto, Danang. 2015. Penelitian Sumber Daya Manusia. Yogyakarta: PT Buku Seru

Sutikno, Sobry M. 2014. Pemimpin dan Orientasi Kepemimpinan, Edisi Pertama Lombok: Holistica

Sutrisno, Edy. 2016. Manajemen Sumber Daya Manusia. Bandung: PT. Mulia Kencana Semesta

Syarifah F. 2014. Pengaruh Gaya Kepemimpinan Terhadap Kinerja Karyawan Pada Kebun Rimba Belian Inti Kabupaten Sanggau. Program Studi IImu Administrasi Negara. Fakultas IImu Sosial dan IImu Politik. Universitas Tanjungpur : Pontianak

JAS-PT

JURNAL ANALISIS SISTEM PENDIDIKAN TINGGI ISSN $2580-5339$ elSSN $2620-5718$

Volume 4

Nomor 1

JULI 2020

Hal 33 - 46

FORUM DOSEN INDONESIA
Thofa, Miftah. 2013. Kepemimpinan dalam Manajemen. PT. Raja Grafindo Persada, Jakarta.

Y. Ruyatnasih. 2013. Pengaruh Gaya Kepemimpinan Terhadap Kinerja Karyawan PT. Mitrabuana Jayalestari Karawang Jurnal Manajemen Vol. 10 No. 3 1-18

Veithzal Rivai. 2014. Manajemen Sumber Daya Manusia Untuk Perusahaan. PT. Rajagrafindo Persada. Jakarta. 